\title{
CANINE-ASSISTED THERAPY AND THE IMPROVEMENT OF PHYSICAL CHARACTERISTICS IN DISABLED CHILDREN: A PILOT STUDY
}

\author{
Ugnė Nedzinskaite் ${ }^{1}$, Julija Mažeikaite் ${ }^{2}$, Mindaugas Paleckaitis ${ }^{1}$, Rolandas Stankevičius ${ }^{2}$ \\ ${ }^{1}$ Lithuanian University of Health Sciences, ${ }^{2}$ Lithuanian University of Health Sciences, \\ Veterinary Academy
}

Keywords: animal-assisted therapy, canitherapy, dogs, physiotherapy, disability, children, pediatrics.

\begin{abstract}
Summary
Materials and methods. Three groups of mentally disabled children of different age participated in dog-assisted therapy sessions twice per week for two months. Motor skills evaluation was based on the Bruininks-Oseretsky motor skills evaluation test (short version). Isometric torso muscle endurance tests were based on Ito, McIntosh and McGill. The ability to focus and memorise exercises and the ability to understand and perform them was also evaluated.

Results. Movement perception and performance, as well as ability to focus and memorise the movement sequel improved after canine-assisted exercise sessions. The most significant changes in performance were observed in the torso muscle static endurance test, push-ups, fine motor skills, and coordination $(\mathrm{p}<0.001)$.

Conclusion. Dogs can be successfully used as motivation for the performance of various task or to lower psychological tension and anxiety during exercise sessions. It is hoped that the results of this study will be used for the development of formal dog-assisted therapy guidelines for use in physical therapy with mentally disabled children.
\end{abstract}

\section{Introduction}

Animal-assisted therapy (AAT) and its positive outcomes on various physical and mental qualities have been highlighted and applied worldwide over the past two decades. The benefits of this type of therapy have been observed among people of varying gender, health state, and age. Dogs are the most commonly used animals for the purpose of improving human wellbeing, particularly among children, which receive both inpatient and outpatient treatment in hospitals and are typically the focus population of existing research. Studies have shown that, in presence of therapy dogs, children with various developmental disorders can concentrate easier and that their playfulness increases. Notably, such an effect could not be mimicked with an artificial dog or other toy [1]. In another study examining the social outcomes of AAT, animal interventions affected the improvement of communication and increased socialisation among people with intellectual disabilities $[2,3]$. AAT does not only help with essential daily life and communication skills. Additionally, mentally and physically disabled children learned how to cope with unpleasant feelings and used their bodies better [4]. The positive effects of dog-assisted therapy can also aid in helping children with autism spectrum disorder and can even increase their interest in school attendance $[5,6]$. Some previous studies focused on single-case reports when working with intellectually disabled children [7]. In other cases, dog-assisted therapy was applied to healthy children school surroundings and universities [8-12]. However, the demand for service animals in classes for children with special needs is also rising [13]. As such, the present study explores the effectiveness of integrating dog-assisted therapy into school curriculums for children with different disabilities, as well as the outcomes it has in motivating children to improve their physical condition.

The aim of the present study was to evaluate whether dog-assisted therapy sessions integrated into the curriculum of a school for mentally disabled children can benefit the outcomes of physical therapy.

\section{Materials and methods}

Participants. The present study was performed at a public school in Kaunas, Lithuania, where several classes were specially integrated for mentally or physically disa- 
bled children. The children selected for the present study had a medically proven disability such as Down syndrome, cerebral palsy, intellectual disability, or autism spectrum disorder. Children were divided to three groups according to their age and the class they attended at school. Group No. 1 consisted of 11 children aged 9-11 (8 males and 3 females). Group No. 2 consisted of 10 children aged $18-19$ years ( 3 males and 7 females). Lastly, Group No. 3 consisted of 7 children aged 11-13 years ( 2 males and 5 females).

Procedure. Exercise sessions with dogs were held twice a week, with each session lasting 45 minutes. The sessions spanned two months, for a total of 16 sessions per group. Consent was gained from the parents of each child. Parents also completed questionnaires that provided information regarding their child's health condition (e.g., any contraindications for dog-assisted therapy). Safety precautions were taken seriously, with each session beginning with a reminder for children about safety rules when communicating with animals. They were also reminded to wash their hands after each session.

A total of six dogs and their handlers participated in the study. Various dog breeds were used, which are presented in Table 1. The dogs ranged from 2 to 10 years in age, while their experience in animal-assisted therapy ranged from 1 to 7 years. All dogs were vaccinated, dewormed, and periodically checked by veterinarians. The selection of a particular dog for each session was based on the psychological and physiological qualities of each individual dog (size, speed, known commands) and the state of the dog's health. Dogs No. 1, No. 4, and No. 5 participated most often because they were more tolerant to the workload, had more experience in dog-assisted therapies, and could learn new commands for sessions more rapidly.

The purpose of each dog differed according to the task. In static tests, a dog would "help" children to maintain a balanced body position (e.g., supporting a leg). When performing the static back muscle endurance test, a dog would have to lay on the buttocks of the child, thereby supporting the lower part of the child's body. During active tasks such as fine motor exercises, push-ups, or the movement perception test, the dog was considered as motivation to act; if the child performed the movements correctly, he could give a command to the dog and reward it with a treat himself - thus obtaining the positive feeling of "being in control". For balance tests, the dogs would perform the task alongside the child - even sitting or standing in a similar way. When children had to memorise the sequence of exercise movements, a dog was included in that sequence (Table 1).

Measures. The participants were evaluated twice - before and after two months of sessions. Motor skills evaluation exercises for children were based on the Bruininks-Oseretsky motor skills evaluation test (short version) and isometric torso muscles endurance tests based on Ito, McIntosh and McGill [14, 15, 16]. Notably, the ability of each child to understand and perform the exercises was considered; therefore, some adjustments were made to make the tasks easier for children. The following portions of the Bruininks-Oseretsky test were used: a test of balance while standing on one foot, fine motor skills test, bilateral coordination test, upper limb coordination test (with a tennis ball), and a test of strength while performing push-ups.

Balance test. The participant must stand on one leg, holding their arms at their hips or sides, while the free leg is bent and held Standing time is measured using

Table 1. Characteristics of dogs.

\begin{tabular}{|l|c|c|c|c|c|c|}
\hline $\begin{array}{l}\text { Dog number / } \\
\text { Characteristics }\end{array}$ & $\mathbf{1}$ & $\mathbf{2}$ & $\mathbf{3}$ & $\mathbf{4}$ & $\mathbf{5}$ & $\mathbf{6}$ \\
\hline Breed & $\begin{array}{c}\text { Mixed- } \\
\text { breed }\end{array}$ & $\begin{array}{c}\text { Mixed- } \\
\text { breed }\end{array}$ & Chihuahua & $\begin{array}{c}\text { Siberian } \\
\text { husky }\end{array}$ & $\begin{array}{c}\text { Siberian } \\
\text { husky }\end{array}$ & $\begin{array}{c}\text { Brabant } \\
\text { griffon }\end{array}$ \\
\hline Gender & Male & Male & Female & Male & Male & Male \\
\hline Age (in years) & 4 & 3 & 3 & 7 & 10 & 2 \\
\hline $\begin{array}{l}\text { Experience in } \\
\text { therapy (years) }\end{array}$ & 3 & 1.5 & 2.5 & 6 & 7 & 10 \\
\hline
\end{tabular}

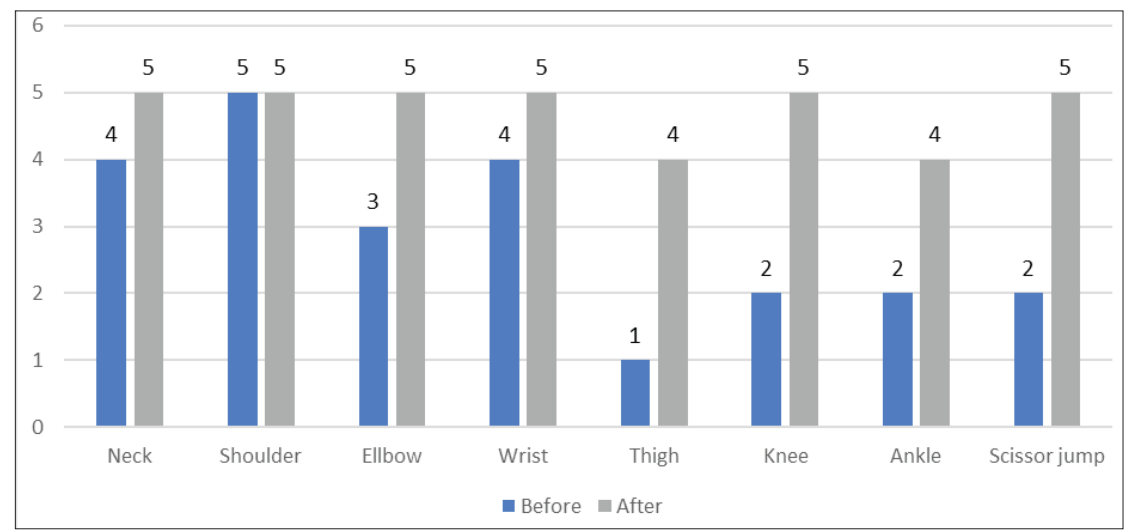

Figure 1. Medians of movement perception and performance before and after AAT sessions. 
a chronometer, and the exercise is terminated if the child places the bent leg on the ground - or after 15s.

Fine motor skills test. The participant must place as many flat, coin-shaped circles into a special tray as they can during $15 \mathrm{~s}$. The exercise is stopped after $15 \mathrm{~s}$, and the amount of correctly placed circles is counted.

Bilateral coordination test. The arm and leg of a chosen side are placed in front, as if the person is walking (arm held high). The arm and leg of the opposite side is placed in the opposite direction. After the signal, participants jump up and have to change the direction of their hands and legs into the opposite one. The movement is correctly performed if the arm and leg of the same side are moving in sync and no additional moves are made. The exercise is counted until five correct movements.

Ball test. The participant holds a ball in their hand in front of them. After the signal, the child throws the ball down

Table 2. Evaluation of movement perception of ability to perform.

\begin{tabular}{|c|c|c|c|c|c|}
\hline \multicolumn{3}{|c|}{ Median } & \multirow{2}{*}{$\begin{array}{c}\begin{array}{c}\text { Mini- } \\
\text { mum }\end{array} \\
1\end{array}$} & \multirow{2}{*}{$\begin{array}{c}\begin{array}{c}\text { Maxi- } \\
\text { mum }\end{array} \\
5\end{array}$} & \multirow{2}{*}{$\begin{array}{c}\text { P value } \\
<0.001\end{array}$} \\
\hline \multirow{2}{*}{ Neck } & Before & 4 & & & \\
\hline & After & 5 & 4 & 5 & \\
\hline \multirow{2}{*}{ Shoulder } & Before & 5 & 1 & 5 & \multirow[t]{2}{*}{0.180} \\
\hline & After & 5 & 3 & 5 & \\
\hline \multirow{2}{*}{ Ellbow } & Before & 3 & 1 & 4 & \multirow[t]{2}{*}{$<0.001$} \\
\hline & After & 5 & 1 & 5 & \\
\hline \multirow{2}{*}{ Wrist } & Before & 4 & 1 & 5 & \multirow[t]{2}{*}{$<0.000$} \\
\hline & After & 5 & 3 & 5 & \\
\hline \multirow{2}{*}{ Thigh } & Before & 1 & 1 & 4 & \multirow[t]{2}{*}{$<0.001$} \\
\hline & After & 4 & 1 & 5 & \\
\hline \multirow{2}{*}{ Knee } & Before & 2 & 1 & 4 & \multirow[t]{2}{*}{$<0.001$} \\
\hline & After & 5 & 1 & 5 & \\
\hline \multirow{2}{*}{ Ankle } & Before & 2 & 1 & 2 & \multirow[t]{2}{*}{$<0.001$} \\
\hline & After & 4 & 1 & 5 & \\
\hline \multirow{2}{*}{$\begin{array}{l}\text { Scissor } \\
\text { jump }\end{array}$} & Before & 2 & 1 & 4 & \multirow[t]{2}{*}{$<0.001$} \\
\hline & After & 5 & 1 & 5 & \\
\hline
\end{tabular}

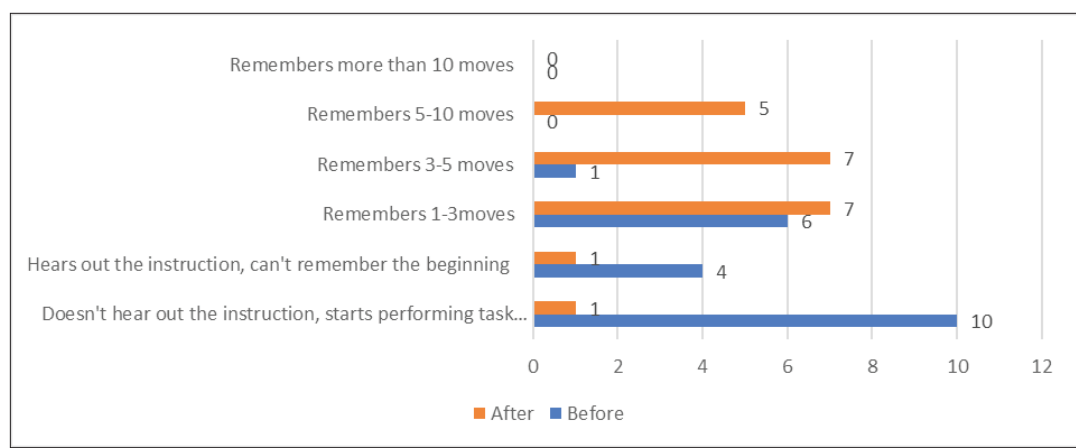

Figure 2. Childrens' ability to focus and memorize the movement sequel. and beats the ball back with the other hand. The movement is then repeated with the opposite hand throwing and the other one beating the ball. The movement is incorrect if the participant does not switch hands, catches and holds the ball, cannot beat back the ball, or the ball falls somewhere else. A maximum of ten correct movements are counted.

Push-ups (evaluation of power). This movement is performed either from a plank position or facilitated one (knees and elbows on the ground). Time is measured using a chronometer for 30s. Movements are held correctly if the participant's pelvis and thighs do not touch the ground and the body is held straight. After the allotted time, the quantity of correctly performed push-ups is counted.

Static back muscle endurance test. During this exercise, support for lumbar lordosis was used in order to avoid placing too much load on the lumbar portion of the spine when stretching. The child lays down on their abdomen and must lift their chest and arms from the support with their arms held behind their head. This position is maintained as long as possible and until the participant can comfortably breathe. The elevation angle, which is formed between the body and horizontal line, must be approximately $15^{\circ}$. When the participant deviates $\pm 10^{\circ}$, the exercise is stopped. Static back muscle endurance is measured using a chronometer. Maximum duration of the exercise is 300s.

Side muscle endurance test. The participant must lay on their side in a such way that the upper leg is in front and the lower leg is behind (position similar to walking), the legs are straight, and the upper hand is placed on the opposite shoulder. The lower hand is bent over the elbow at $90^{\circ}$ and the body is lifted from the ground. This position must be maintained as long as possible, and the test ends when the participant can no longer maintain the position and places their pelvis on the ground. Once one side of the body is measured, the same test is then applied on the opposite side.

Plank test. The participant must lay down, facing the ground. The participant must lean on their toes, while their elbows must be flexed to $90^{\circ}$ with their legs straight. The test is completed when the participant cannot maintain their position any longer. The duration that the position was maintained for is measured with a chronometer, for a maximum of $15 \mathrm{~s}$.

Memory and ability to focus. A scale from 1 to 6 was used for the evaluation of this ability: 1 point - child does not hear the instructions and begins performing the task immediately. 2 points - child hears the instruction but cannot remember the beginning. 3 points - remembers one 
to three moves; 4 points - remembers three to five moves; 5 points- remembers five to ten moves; 6 points - remembers over ten moves.

Movement perception and ability to perform. A scale from 1 to 5 was used for the evaluation of this ability: 1 point - child cannot understand the move, and there are no attempts to perform it; 2 points - child cannot understand the move and performs it incorrectly; 3 points - child understands the move, attempts to perform it, and fails. 4 points - child understands the move and performs incorrectly or with help; 5 points - understands the move, performs incorrectly.

Data analysis. Statistical analysis of the data was performed using IBM SPSS(Statistical Package for the Social Sciences) 17.0 Software. Wilcoxon criteria and McNemar criteria were used. The results were considered statistically significant if $p$ values were $<0.05$.

\section{Results}

The abilities of children were re-evaluated after two months of exercise sessions. Before secondary testing, the exercises were once again explained, and an example of moves was shown. Dogs were also present during the secondary evaluation.

An evaluation of children's ability to perceive and perform specific moves before and after AAT sessions is presented in Figure 1. The highest median value before the exercises with the assistance of dogs was observed for shoulder movement (min.1, max.5), while the lowest was for thigh movement(min.1, max.4). Following the completion of the AAT sessions, the resulting median values were higher for the neck, shoulder, elbow, wrist, knee, and scissor jump movements. Only the ankle and thigh movement median values remained below the maximum score; however, these improved to a score of 4 . The results indicate that there were still some movements in the AAT sessions for which the minimum score did not changed, thereby suggesting that some children still could not cope with the perception and performance of the given moves. Moreover, exercises where the minimum values remained identical included the elbow, thigh, knee, ankle and scissor jump movements. Minimum scores for neck, shoulder, and wrist movements changed, with the lowest score (3) among them indicating that, after the AAT sessions, all of the movements were understood, and only performance abilities differed. As observed in Table 2, the difference in median values before and after AAT significantly differed among all movements, with the exclusion of the shoulder movement only.

Results related to children's ability to focus on instructions and memorise movement sequences are presented in Figure 2. These results indicate that, before AAT, most of the children had issues even focusing and listening to instructions. Ten of them could not listen to the instructions, while six remembered only one to three moves, and four of them managed to hear the task but could not remember it. Following AAT, the children could manage most movements better (seven children in both groups) by either remembering one to three moves or three to five moves, while five children managed to remember five to ten moves following the AAT sessions. According to these results, the children were divided into two groups for statistical analysis: those who remembered at least some moves and those who could not focus, listen to the instructor, or remember anything. McNemar's test determined that there was a statistically significant difference in proportion of children in these two groups before and after AAT sessions $(\mathrm{p}<0.001)$.

The ability to perform several movements was evaluated with the use of a chronometer, with the maximum duration of the position held being counted in seconds. As seen in Table 3 , the majority of mean differences in Bruininks-Oseretsky motor test results before and after AAT are significant, including fine motor skills, coordination, and push-ups ( $\mathrm{p}<0.001)$. Mean static endurance of the torso muscles also increased

Table 3. Bruininks-Osteresky and static endurance and test results before and after AAT sessions.

\begin{tabular}{|c|c|c|c|c|}
\hline \multicolumn{2}{|l|}{ Test } & Mean & \multirow{2}{*}{$\begin{array}{c}\text { Std deviation } \\
0.349\end{array}$} & \multirow{3}{*}{$\begin{array}{l}\text { p value } \\
<0.001\end{array}$} \\
\hline \multirow{2}{*}{$\begin{array}{l}\text { Fine motor } \\
\text { skills }\end{array}$} & Before & 2.48 & & \\
\hline & After & 5 & 0.42 & \\
\hline \multirow{2}{*}{ Coordination } & Before & 0.95 & 0.368 & \multirow{2}{*}{$<0.001$} \\
\hline & After & 3.33 & 0.311 & \\
\hline \multirow{2}{*}{ Balance } & Before & 2.14 & 0.475 & \multirow{2}{*}{0.001} \\
\hline & After & 5.1 & 0.819 & \\
\hline \multirow{2}{*}{ Ball test } & Before & 1.19 & 0.235 & \multirow{2}{*}{0.003} \\
\hline & After & 2.19 & 0.29 & \\
\hline \multirow{2}{*}{ Push ups } & Before & 1.29 & 0.302 & \multirow{2}{*}{$<0.001$} \\
\hline & After & 3.05 & 0.439 & \\
\hline \multirow{2}{*}{$\begin{array}{l}\text { Back muscle } \\
\text { static endu- } \\
\text { rance }\end{array}$} & Before & 3.1 & 1.478 & \multirow{2}{*}{0.001} \\
\hline & After & 7.43 & 1.956 & \\
\hline \multirow{2}{*}{$\begin{array}{l}\text { Torso muscle } \\
\text { static endu- } \\
\text { rance }\end{array}$} & Before & 9.38 & 3.054 & \multirow[b]{2}{*}{$<0.001$} \\
\hline & After & 19 & 4.021 & \\
\hline \multirow{2}{*}{ Plank test } & Before & 7.95 & 3.139 & \multirow{2}{*}{0.004} \\
\hline & After & 13.95 & 4.433 & \\
\hline \multirow{2}{*}{$\begin{array}{l}\text { Lateral right } \\
\text { muscle endu- } \\
\text { rance }\end{array}$} & Before & 3.48 & 1.061 & \multirow[b]{2}{*}{0.001} \\
\hline & After & 8.38 & 2.001 & \\
\hline \multirow{2}{*}{$\begin{array}{l}\text { Lateral left } \\
\text { muscle endu- } \\
\text { rance }\end{array}$} & Before & 4.71 & 1.488 & \multirow[b]{2}{*}{0.012} \\
\hline & After & 8.57 & 1.798 & \\
\hline
\end{tabular}


significantly after the sessions with dogs $(p<0.001)$. The lowest observed changes in the ability to perform was noted for the lateral left muscle endurance test $(\mathrm{p}=0.012)$ and the plank test (position maintenance; $\mathrm{p}=0.004$ ).

\section{Discussion}

The aim of the first exercise session with dogs was to determine whether all participants of the study were able to follow instructions and perform the required exercises. During the warm up exercises, it was noted that many children could not understand neck or elbow movements and the rotation of lower limb joints. Also, nearly all participants could not understand the scissor jump. Some children had disabilities that could have affected the performance of these tasks (e.g., spasticity of the lower limbs, muteness).

Improvement of test results were observed among the other participants, which is congruent with the results of other studies claiming that dog-assisted therapy can be used as a tool for concentration improvement and proper social behaviour development $[1,4,17]$. The results of the primary testing indicated a lack of motor skill development among the children. When evaluating the perception of movement, most children could understand and perform movements of the upper limbs better than those of the lower limbs. Significantly reduced ankle mobility was noted, which is a common sign of diseases such as cerebral palsy, autism spectrum disorder, and intellectual disability [18-21].

Differences between primary and secondary testing among all groups confirmed the hypothesis that dog-assisted therapy sessions implemented in education facilities can improve the motor and physical skills of mentally disabled children [17, 22-24]. Dogs were not only motivating children to perform, but also helped to lower pressure, tension, and anxiety due to performance difficulty, group inner conflicts, and individual qualities. After only a short intervention with the animals, participants were more likely to demonstrate socially appropriate behaviours, a lower occurrence of nondesirable behaviour episodes, and improved motivation to perform the tasks. Such findings were also noted in previous studies $[1,5,25,26]$. Since we focused on the evaluation of physical abilities, positive outcomes in emotional and social qualities were observed and evaluated subjectively. However, other researchers have also highlighted the positive outcomes of dog-assisted therapy in terms of verbal and non-verbal communication as well as social development (Berry et al., 2013). Notably, according to previous studies, implementing such AAT practices into daily school life could benefit autistic children more than having a dog in the household from an early age [26]. Moreover, the application of dog-assisted therapy sessions with mentally and physically disabled children improved their social response, making desirable behaviours more prevalent $[27,28]$.

The positive effect of dog-assisted therapies was also observed among children with autism spectrum disorder [5]. Improvements in social development, verbal and nonverbal communication, as well as the reduced occurrence of autostimulation episodes and aggression outbreaks were also noted $[7,17]$. Furthermore, eye contact had improved, and smiling as a response to pleasant communication occurred more often [26]. The effect of using a real dog in this context surpasses the effect of a robotic equivalent [29].

While the present study has provided strong evidence on the benefits of using dogs for AAT, this research has some limitations. Firstly, only dog-assisted therapy was used, with no comparison to other therapy methods. Also, a variety of study designs among similar studies reduce the possibility of comparing outcomes on the physical wellbeing of mentally and physically disabled children. As previously mentioned, some of the disabilities could also affect the perception and performance of tasks. Since the disabilities of children in different groups varied, we decided to examine the results of movement perception and performance tests for all the children combined, and did not compare them among the three groups, thus opening the effects of age differences for discussion. However, similar limitations were observed in previous studies [4]. As such, further research on these specific features in the context of animal-assisted therapy is needed.

\section{Conclusion}

In the present study, the most significant changes were observed for the torso muscle static endurance test, push-ups, fine motor skills, and coordination. The results for children with severe movement disorders and significant communication and information perception difficulties improved less than that for other portions of the group. However, it is evident that dogs can be successfully used as a motivation for improving the performance of various tasks and lowering tension and anxiety during sessions. The strongest aspect of this study is that we identified the tasks which dogs were most efficient at improving; as such, these tasks could be included in sports classes or physical therapy programmes in schools. It was also determined which movement tests are suitable when evaluating therapy effect. It is hoped that the results of this study will be used in the development of formal dog-assisted therapy guidelines for mentally and physically disabled children in the future.

\section{References}

1. Martin F, Farnum J. Animal-assisted therapy for children with 
pervasive developmental disorders. Western Journal of Nursing Research 2002; 24(6): 657-670.

https://doi.org/10.1177/019394502320555403

2. Maber-Aleksandrowicz S, Avent C, Hassiotis A. A systematic review of animal-assisted therapy on psychosocial outcomes in people with intellectual disability. Research in Developmental Disabilities 2016; 49-50: 322-338.

https://doi.org/10.1016/j.ridd.2015.12.005

3. Scorzato I, Zaninotto L, Romano M, Menardi C, Cavedon L, Pegoraro A, et al. Effects of dog-assisted therapy on communication and basic social skills of adults with intellectual disabilities: a pilot study. Intellectual and developmental disabilities 2017; 55(3): 125-139.

https://doi.org/10.1352/1934-9556-55.3.125

4. Elmac1 D, Cevizci S. Dog-assisted therapies and activities in rehabilitation of children with cerebral palsy and physical and mental disabilities. International Journal of Environmental Research and Public Health 2015;12(5): 5046-5060. https://doi.org/10.3390/ijerph120505046

5. Siewertsen C, French E, Teramoto M. Autism spectrum disorder and pet therapy. Adv Mind Body Med 2015; 2(29): 22-25.

6. O'Haire M, McKenzie S, McCune S, Slaughter V. Effects of classroom animal-assisted activities on social functioning in children with autism spectrum disorder. The Journal of Alternative and Complementary Medicine 2014; 20(3): 162-168. https://doi.org/10.1089/acm.2013.0165

7. Silva K, Correia R, Lima M, Magalhães A, de Sousa L. Can dogs prime autistic children for therapy? Evidence from a single case study. The Journal of Alternative and Complementary Medicine, 2011; 17(7): 655-659.

https://doi.org/10.1089/acm.2010.0436

8. Ward-Griffin E, Klaiber P, Collins H, Owens R, Coren S, Chen F. Petting away pre-exam stress: The effect of therapy dog sessions on student well-being. Stress And Health 2018; 34(3): 468-473.

https://doi.org/10.1002/smi.2804

9. Binfet J, Passmore H, Cebry A, Struik K, McKay C. Reducing university students' stress through a drop-in canine-therapy program. Journal of Mental Health 2017; 27(3): 197-204. 10.

10. Schmitz A, Beermann M, MacKenzie C, Fetz K, Schulz-Quach C. Animal-assisted therapy at a university centre for palliative medicine - a qualitative content analysis of patient records. BMC Palliative Care 2017; 16(1). https://doi.org/10.1186/s12904-017-0230-z

11. Fiocco A, Dunse, A. The buffer effect of therapy dog exposure on stress reactivity in undergraduate students. International Journal of Environmental Research and Public Health 2017; 14(7): 707. https://doi.org/10.3390/ijerph14070707

12. Brelsford V, Meints K, Gee N, Pfeffer K. Animal-assisted interventions in the classroom-a systematic review. International Journal of Environmental Research and Public Health
2017:14(7): 669 .

https://doi.org/10.3390/ijerph14070669

13. Minchella L. Hot topics in special needs school nursing. NASN School Nurse 2011; 26(2): 78-81. https://doi.org/10.1177/1942602X11399385

14. Ito T, Shirado O, Suzuki H, Takahashi M, Kaneda K, Strax T. Lumbar trunk muscle endurance testing: An inexpensive alternative to a machine for evaluation. Archives of Physical Medicine And Rehabilitation 1996; 77(1): 75-79.

https://doi.org/10.1016/S0003-9993(96)90224-5

15. McIntosh G, Wilson L, Affieck M, Hall H. Trunk and lower extremity muscle endurance: normative data for adults. Journal of Rehabilitation Outcome Measurement 1998; (2): 20-39.

16. Abdelraouf $\mathrm{O}$, Abdel-aziem A. The relationship between core endurance and back dysfunction in collegiate male athletes with and without nonspecific low back pain. International Journal of Sports Physical Therapy 2008;11(3): 337-344.

17. Esteves, S, Stokes T. Social effects of a dog's presence on children with disabilities. Anthrozoös 2008; 21(1): 5-15. https://doi.org/10.1080/08927936.2008.11425166

18. Hinchcliffe A. Children with cerebral palsy. New Delhi: SAGE 2009;13-15, 16, 19, 20, 21.

19. Gowen E, Hamilton A. Motor abilities in autism: a review using a computational context. Journal of Autism and Developmental Disorders 2012; 43(2): 323-344.

https://doi.org/10.1007/s10803-012-1574-0

20. Provost B, Heimerl S, Lopez B. Levels of gross and fine motor development in young children with autism spectrum disorder. Physical \& Occupational Therapy in Pediatrics 2007; 27(3): 21-36.

https://doi.org/10.1300/J006v27n03_03

21. Ming X, Brimacombe M, Wagner G. Prevalence of motor impairment in autism spectrum disorders. Brain And Development 2007; 29(9): 565-570.

https://doi.org/10.1016/j.braindev.2007.03.002

22. Velde B, Cipriani J, Fisher G. Resident and therapist views of animal-assisted therapy: Implications for occupational therapy practice. Australian Occupational Therapy Journal 2005; 52(1): 43-50.

https://doi.org/10.1111/j.1440-1630.2004.00442.x

23. Rondeau L, Corriveau H, Bier N, Camden C, Champagne N, Dion C. Effectiveness of a rehabilitation dog in fostering gait retraining for adults with a recent stroke: A multiple single-case study. Neurorehabilitation 2010; 27(2): 155-163, 2010.

24. Maltseva M, Melnikova E, Shmonin A, Skoromets A, Ivanova G. Canis-therapy (Dog-Assisted therapy) is the rehabilitation for patients with stroke in the recovery phase: single-blind study of the efficacy. The Journal of Restorative Medicine \& Rehabilitation 2013; (6): 70-73.

25. Cole K, Gawlinski A, Steers N, Kotlerman J. Animal-assisted therapy in patients hospitalized with heart failure. American 


\section{4}

Journal of Critical Care 2007; (16): 575-585.

26. Berry A, Borgi M, Francia N, Alleva E, Cirulli F. Use of assistance and therapy dogs for children with autism spectrum disorders: A critical review of the current evidence. The Journal Of Alternative And Complementary Medicine 2013; 19(2): 73-80. https://doi.org/10.1089/acm.2011.0835

27. Grandgeorge M, Tordjman S, Lazartigues A, Lemonnier E, Deleau M, Hausberger M. Does pet arrival trigger prosocial behaviors in individuals with autism? Plos One 2012; 7(8): e41739.

https://doi.org/10.1371/journal.pone.0041739

28. Hall S, Wright H, Mills D. What factors are associated with positive effects of dog ownership in families with children with autism spectrum disorder? The development of the Lincoln autism pet dog impact scale. Plos One 2016; 11(2): e0149736. https://doi.org/10.1371/journal.pone.0149736

29. Silva,K, Lima M, Santos-Magalhães A, Fafiães C, de Sousa L. Can dogs assist children with severe autism spectrum disorder in complying with challenging demands? An exploratory experiment with a live and a robotic dog. The Journal of Alternative and Complementary Medicine 2018; 24(3): 238-242.

https://doi.org/10.1089/acm.2017.0254

\section{KANITERAPIJA IR NEĮGALIŲ VAIKŲ FIZINĖS BŪKLE்S GERINIMAS: BANDOMASIS TYRIMAS U.Nedzinskaitė, J.Mažeikaitė, M.Paleckaitis, \\ R.Stankevičius}

Raktažodžiai: gyvūnų asistuojama terapija, kaniterapija, šunys, kineziterapija, negalia, vaikai, pediatrija.
Santrauka

Tikslas. Šio tyrimo tikslas buvo įvertinti, ar terapiniai užsièmimai su šunimis, integruoti ị psichikos negalią turinčių vaikų ugdymo programą, gali pagerinti kineziterapijos užsièmimų rezultatus.

Metodai. Trys skirtingo amžiaus psichikos negalią turinčių vaikų grupès du mėnesius per savaitę dalyvavo šunų terapijos užsièmimuose. Motorinių ịgūdžių vertinimas buvo grindžiamas „Bruininks-Oseretsky" motorinių ịgūdžių vertinimo testu (trumpaja versija). Izometriniai liemens raumenų ištvermès testai parengti pagal Ito, McIntosh ir McGill. Taip pat buvo vertinamas vaikų gebejjimas susikaupti ir įsiminti pratimus bei gebejjimas juos suprasti ir atlikti.

Rezultatai. Judesių suvokimas ir atlikimas, taip pat gebejjimas susikaupti ir ịsiminti pratimų seką po užsièmimų su šunimis pagerejjo. Reikšmingiausi fiziniai pokyčiai buvo pastebèti atliekant liemens raumenų statinès ištvermès testą, atsispaudimus, smulkiosios motorikos ir koordinacijos testus $(p<0,001)$.

Išvados. Šunys gali sėkmingai būti naudojami kaip motyvacija atlikti įvairias užduotis arba sumažinti psichologinę įtampą ir nerimą mankštos metu. Tikimasi, kad šio tyrimo rezultatai bus panaudoti formuojant oficialias kaniterapijos gaires, skirtas naudoti kineziterapijos su psichikos negalią turinčiais vaikais metu.

Adresas susirašinèti: nedzinskaite.ugne@gmail.com

Gauta 2019-10-18 